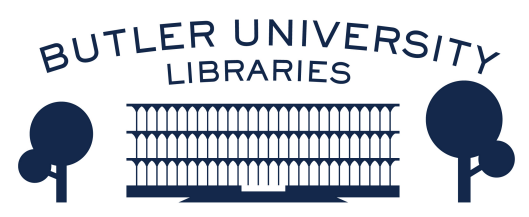

Journal of Hindu-Christian Studies

Volume 8

Article 14

January 1995

\title{
Book Review: "Monastic Life in the Christian and Hindu Traditions: A Comparative Study"
}

\author{
Harold Coward
}

Follow this and additional works at: https://digitalcommons.butler.edu/jhcs

Part of the Religion Commons

\section{Recommended Citation}

Coward, Harold (1995) "Book Review: "Monastic Life in the Christian and Hindu Traditions: A Comparative Study"," Journal of Hindu-Christian Studies: Vol. 8, Article 14.

Available at: https://doi.org/10.7825/2164-6279.1119

The Journal of Hindu-Christian Studies is a publication of the Society for Hindu-Christian Studies. The digital version is made available by Digital Commons @ Butler University. For questions about the Journal or the Society, please contact cbauman@butler.edu. For more information about Digital Commons @ Butler University, please contact digitalscholarship@butler.edu. 
"empowerment", as attested to by the author himself "from a number of very potent and unsought dreams of Mā with which she blessed him, though he had never even met her". Similar gifts are claimed for Śyāma Mātāji and Amma Mātā Amritānandamayi. He seems particularly impressed with Anasūyā Devī, who died in 1985. Little is known of her in the West, Conway says, but "since Amma's return to Formless Light, her Divine Motherly Presence is still profoundly experienced".

The disciples of each of the remarkable women described here will find in the book fodder to reaffirm their faith. Other readers may find the anecdotes and quotations of passing interest from the standpoint of comparative religion. But Conway's uncritical tone and florid language are stylistically irritating. His personal affirmations of faith seem insincere at times and, contrary to his intention, invite a healthy scepticism.

Heather Botting

University of Victoria

\section{Monastic Life in the Christian and Hindu Traditions: A Compara-} tive Study. Austin B. Creel and Vasudha Narayanan (Eds.). Lewiston, N.Y.: Edwin Mellen Press, 1990, xiii +593pp.

\section{RESULTING FROM A research} conference held at the University of Florida in 1985 , this volume is the first attempt by a team of scholars who are specialists on monasticism to offer a comparative HinduChristian study of the topic. The editors wisely claim that it is but an introductory study and Juergensmeyer in his concluding chapter points out that rather than being comparative, most of the volume's essays are studies of specific aspects of monastic life in either Hindu or Christian case studies - with the reader left to do the comparative analysis. While this may frustrate some readers, it has the advantage of avoiding facile comparisons and ensuring that the studies included do offer in-depth presentations of various aspects of Hindu and Christian monasticism. Juergensmeyer's conclusion, "The Monastic Syndrome", offers a helpful comparative analysis of the essays so that the comparative study promised in the title is not left entirely to the reader to construct. While some of the authors (e.g. Elder, Linge, and Cousins) do make reference to the comparative task at hand, many authors give the announced unifying thread of the volume (The
Comparative Study of Hindu and Christian Monastic Life) little mention, and this is my major criticism of the book. Also, T. N. Madan's chapter on the Pandits of Kashmir focuses on their solid commitment to the householder rather than monastic life, which they deny. Consequently, this essay does not fit the theme of the volume and should have been excluded by the editors. Aside from these critical comments, I found much of value in the book.

If the reader is interested in the comparative study of monastic life, I recommend that one begin by reading Juergensmeyer's fine concluding overview and comparative analysis of the essays included. Then one will be in a better position to approach the individual case studies and do the comparative exercise for oneself. Juergensmeyer convincingly proposes that one can find a common pattern of monastic behaviour across Christianity and Hinduism which he summarizes as "a religious calling to undertake an intense personal spiritual activity that separates those involved in it from ordinary society and binds them together in same-sex kindred fellowships that provide ideal alternatives to 
the ordinary world" (p.556). While most of the Christian and Hindu case studies in the volume fit into this definition, there are several that do not. Vasudha Narayanan demonstrates that within Hinduism Ramanuja introduced a new model of renunciation both within and without the world - much like the Christian mendicant orders. Ramanuja's concept of surrender (prapatti), especially as inspired by the Tamil poet saints (the Alvars), opened the practice of renunciation to men or women of any caste. The rejection of caste, scripture, and the impurity of women also marks the Virasaiva Lingayates as restating asceticism within worldly life, as Michael shows in his essay. Hawley finds many of the same patterns to be present in North Indian bhakti saints such as Kabir and Surdas. Within Christianity, Geary suggests that the Protestant Reformation, rather than renouncing human society and establishing a monastic counter-culture, aimed to transform society itself.

Studies of orthodox Christian and Hindu monastic life include: Linge's fine analysis of the development of asceticism in the Desert Fathers (with many insightful comparisons to Hindu yoga); Cousins's tracing of the evolution of the classical Christian monastic life ideal from the 6th to the 10th centuries; Timko's fine article on "Patterns of Monastic Prayer"; Yocum's field study of a non-Brahman Tamil Saiva Mutt; and Rosenwein's cartographic analysis of the Cluny monastery and its branch operations. Notable by its absence on the Christian side was any treatment of Orthodox Christianity, especially its development of spiritual fathers and the Jesus Prayer.

In spite of my criticism, this is a most valuable volume - the best work in English on the topic to date. A glossary, bibliography, and index add to the volume's usefulness.

Harold Coward

University of Victoria

\section{Christianity and World Religions. Paths of Dialogue with Islam, Hinduism, and Buddhism. Hans Küng with Josef van Ess, Heinrich von Stietencron, Heinz Bechert. Peter Heinegg (Tr.). Maryknoll, N.Y.: Orbis Books, (1986) 1993.}

\begin{abstract}
HANS KÜNG'S BOOK Christianity and World Religions. Paths of Dialogue (1993) is a reprint of a book which was first printed in German in 1984 and in English in 1986. It is not a book for seasoned participants in interreligious dialogue, rather it is an introductory text for those who wish to acquaint themselves with "the absolutely necessary knowledge about the great religions of the world: Islam, Hinduism, and Buddhism" (p.xx). As such, it is more a general survey, rather than an intricate examination of the more esoteric elements of
\end{abstract}

these religions, or the finer points that figure in contemporary endeavours at dialogue.

The omission of Judaism would seem a discrepancy, even grounds for rebuke, but the volume needs to be placed in the context of Küng's own trajectory in first ecumenical, then interreligious developments. In the foreword to the second edition, Küng himself provides a brief recap of his own struggles with the Christian formula of extra ecclesiam nulla salus, since the revolutionary rapprochement introduced by the Second Vatican Council (1962-65). Küng reflects that in his early efforts, On Being $a$ 